\title{
A VÁROSOKRA ALAPOZOTT TERÜLETPOLITIKA KONCEPCIONÁLIS MEGALAPOZÁSA
}

\section{(Conceptional Establishment of Town Based Regional Politics)}

\section{FARAGÓ LÁSZLÓ}

Kulcsszovak:

telepiiléspolitika várospolitika policentrizmus növekedési pólusok növekedési centrum régióközpont terïletitervek OTK

E tanulnainyban elözetesen tisztäzni kívainom. hogy melyek lehetnek a meguijított (valójában „retro") teriiletpolitika régen tudott, de átmenetileg hättérbe szorult alapjai. Miként lehet integrálni a város-falu kategóriákat, és a városokra koncentrált fejlesztéspolitikảnak melyek a regionális gazdaságtani alapjai. Ezt követöen áttekintem az EU terïletpolitikäjának témánkat érintó hangsúlyváltozásait. A magyar elötörténet tárgyalásával azt kívánom bemutatni, hogy a mai megvïlaszolandó kérdések nem ij keletũek, történelmi adósságokra kell 21. századi válaszokat adni. A „retro" területfejlesztési politika uijdonsága. hogy középpontjában a városrégiókra alapozott, policentrikus fejlesżtés ăll, amely újszerüen integrálja a vidéket, ezáltal feloldja a korábbi város-falu dichorómiát. A koncentrált decentralizációt az elérhetôség (a hozzáférhetôség) javítása kell hogy kisérje.

Vitapartnereimtől, diákjaimtól meg szoktam kérdezni, hogy a városoknak vannak-e régióik ${ }^{1}$, vagy a régióknak vannak-e (kijelölhető) központjaik? A válaszokból tudni lehet, hogy ki milyen területpolitikai elveket vall, a térhasználatokból, a települési funkciókból alulról építi-e fel a térstruktúrát, vagy a központi feladatok elosztásában gondolkodva fentröl lefelé haladva ,regionalizál”.

Az elmúlt két évtized területpolitikájának legnagyobb hibája az volt, hogy felborult a területfejlesztés belső egyensúlya, nem a súlyának megfelelő figyelmet kapott a városfejlesztés. Ma már könnyen belátható, hogy az uniós területpolitikának is csak egy eleme a régió, és a versenyképesség megteremtésében, a Lisszaboni stratégia megvalósításában a városoknak kiemelt szerepet kell biztosítani. Az ESDP prioritásai, politikai opciói sugallják, és a 2007-2013-ra vonatkozó tervezési iránymutatások megkövetelik a városi (urbánus térségi) dimenzió megjelenítését, kezelését. Elkerülhetetlen a magyar területpolitika megújítása, és ennek során tovább nem halasztható a városfejlesztés erősítése és megjelenítése a kormányzati struktúrában, és a városoknak nagyobb szerepet kell kapniuk a fejlesztési döntéshozatalban.

\section{A város és vidékének integrációja az urbanizáció újabb szakaszában}

A városok egyre növekvỏ mértékben koncentrálják és használják fel a fejlesztési forrásokat, és ennek eredményeként a teljesítmény (számbavétele) is ott jelentkezik. A vidék ,tartalma” megváltozik, a hagyományos város-falu diszjunkció értelmét veszti és a városokhoz integrálódott „,vidéki” települések (falvak/községek) közvetett módon hozzájárulnak az egész térség fejlödéséhez. 
Általában arról folyik a diszkusszió, hogy mi a falu és a város, a vidék és a városias területek közötti különbség. Fordítsuk meg a kérdést, és nézzük meg, hogy mi bennük a közös, a különbségek ellenére miként részei az egységes településrendszernek. A településhálózat történelmi kategória, amely a mindenkori konkrét társadalmi-gazdasági formák által meghatározva létezik, így a város és a falu megkülönböztetése, egymásra vonatkoztatása is korszakonként változik. Mindkettő formailag embercsoportok lakóhelye, a társadalmi lét helyhez kötött objektivációinak lokális együttese, lényegét tekintve társadalmi képzödmény.

A lokalitás, a kisléptékủ térhasználatok együttese, amely legjobban az életvilág (Habermas) kategóriájával írható le, amely az ember mindennapi életének világa, olyan ,jelenségtér", amelyet az ember saját céljainak megfelelöen egyre nagyobb mértékben alakít, folyamatosan újrakonstituál. Ez azt jelenti, hogy egyének, családok és azok különböző csoportjai számára más és más. Vannak, akiknek a térhasználata a lakott település töredékére terjed ki, és vannak, akik egységként használnak több települést, például kihasználják a kisebb falusias település elönyeit, mint lakóhely, a városban dolgoznak és nap mint nap igénybe veszik a központi város különböző szolgáltatásait.

A város és a falu elkülönülése - egyidejü létrejötte - a társadalmi munkamegosztás fejlődésének és egy koncentrációs folyamatnak az eredménye. A glokalizáció hatására a települések közötti funkciómegosztás is átalakul. Például ma már nem igaz a korábbi tétel, miszerint a meghatározó vidéki gazdasági tevékenység a mezögazdaság. Ma már a ,falusi” lakosságnak is csak kb. 10-15\%-a él kizárólag mezőgazdaságból, 25-35\%-a helyi feldolgozóiparban és szolgáltatásokban dolgozik, és a munkavállalók fele számára a városok nyújtanak munkalehetőséget.

A jövöben a falvak, a falusias térségek fejlödését egyre inkább a központi városok és az azokhoz füződö kapcsolataik határozzák meg. Az erös városok által dominált vidéki térségek, az urbánus kistérségek fejlödését a város által generált urbanizációs trendek határozzák meg. Az alapvetően vidékies (rurális) kistérségekben, ahol a város is döntően a vidéki gazdaság közigazgatási, szolgáltató központja, ott a városokban is a vidéki térség igényei dominálnak, a város a vidéke függvényében, annak szükségletei szerint fejlődik. Ma már egyre inkább értelmét veszti a városok és a falvak hagyományos elveken alapuló elválasztása és fejlesztésük külön kezelése. Az urbánus és rurális folyamatok egyre nehezebben elválaszthatók, és a fejlődési trendeket ezek integrációja határozza meg. A városokban történtek soha sem voltak értelmezhetőek a környező rurális tértől függetlenül. A szuburbanizációnak, a dezurbanizációnak vagy a counter-urbanizációnak mind közvetlen vonatkozásai voltak és vannak a környező „falvakra”. Ezt jelöli a „rurbanizáció” fogalma, vagy a széles értelemben vett urbanizáció újabb szakasza, de beszélhetünk akár poszturbanizációról is. Például Budapest elmúlt évben tapasztalt népességvesztésének döntő része a környékre való kiköltözést jelentette, de ezek az emberek továbbra is Budapesten dolgoznak, és ott látják el öket (köz)szolgáltatásokkal.

A falusi települések egyre nagyobb hányadát a ,post-produktivitás” jellemzi. Egyre kisebb arányban állítanak elő hagyományos termékeket és inkább lakóhelyi, rekreációs, üdülési, tájfenntartási stb. funkcióik erösödnek. A város-falu kapcsolatrendszert sem a hagyományos mezőgazdasági és ipari termékek cseréje, napi mozgása határozza meg. 
Faragó László: A városokra alapozott területpolitika koncepcionális megalapozása.

Tér és Társadalom, 20. 2006. 2. 83-102. p

A ma oly „divatos” versenyképesség szempontjából is fontos a város és vidékének együtt kezelése. A (köz)szolgáltatások vonzáskörzete, a kisvállalkozások jelentős részének elsődleges piaca a város és vidékét tartalmazó városrégió/kistérség, amely jelentős részben a munkaeró-vonzáskörzetet is jelenti. A város nem környékével rivalizál, és a falvaknak sem ellensége a központi hely, a văros, mint azt a rendszerváltást követően sok kistérségi társulás gondolta. Együtt tagolódnak be a különböző szintủ hálózatokba, a magasabb szintü város környékét is magasabb szintre emeli, a hanyatló város rontja környékének az esélyeit is.

A fenntartható fejlödés eszmerendszere, az ehhez kapcsolódó gazdaság, a környezetipar is erösíti a város és környékének kapcsolatát. E téren új együttmüködési lehetóségek kínálkoznak. Ilyen teruiletek pl. a hulladékkezelés, az ivóvízellátás, az energiagazdálkodás stb. Ez utóbbi új lehetőségeket teremt az együttműködésre. Például a város energiaszükségletét teljes egészében ,importból” is biztosíthatja, de megtermelheti számára a környezỏ rurális terület. Egy erỏmủ, egy távfütést biztosító vállalat használhat gázt, szenet, de akár fát, biomasszát is, igy a vidéki lakosság energiaülttetvényeken megtermelheti az energiaszükséglet egyre növekvô részêt, és a városokban termelödö hulladékból elöállított komposzt javíthatja az energiaültetvények termöföldjét. Egy lakás éves fütéséhez 0,7 hektáron - akár a hagyományos mezőgazdaságból kivont rossz minőségü földön is - megtermelhető a biomasszához szükséges növényzet. Ezáltal a központi város keresletet teremt a vidék számára, munkahelyeket tart fönt a vidéken.

A kistérségi együttmúködés nem egyirányú kapcsolatot jelent, nem csak az lehetséges, hogy a város ellátja a vidéken gazdaságosan nem biztosítható, így többnyire hiányzó funkciókat, hanem a specializáció és funkciómegosztás révén akár arra is lehetőség kínálkozik, hogy valamely funkciót az adott falu teljesítse az egész funkcionális városi körzet számára. Városaink többsége is kis lélekszámú, így számos szolgáltatás hatékony előállításához nincs meg a kritikus tömeg. De a városban vagy a városkömyéken koncentráltan elhelyezett üzemekben gazdaságosabban lehet elóálítani szolgáltatásokat az egész térség számára, mintha azt mindenki külön-külön állítaná elő. Ez különösen igaz a falvakra, ott a lélekszám lehetetlenné teszi a gazdaságossági követelmények teljesítését. Mindezzel nő a vidék népesség megtartóképessége, a város és vidékének versenyképessége, mégpedig fenntartható módon. A város és térsége együtt tesz eleget a komplexitás elvének.

A falvak a hagyományos mezógazdasági funkciójukat elvesztve (szükítve és átalakítva) más új funkciót is teljesíthetnek. Többek között:

- lakóhely,

- üdülóhely,

- napi rekreáció, pihenés,

- ipartelepítés,

- közszolgáltató vállalatok, intézmények telephelye, (szennyvíztelep, hulladéklerakó, kôrház, szanatórium, idősek otthona stb.),

- tájfenntartás, „természetvédelem”, ökológiai egyensúly biztosítása stb. 


\section{A városi központokra koncentráló fejlesztéspolitika alapjai}

A történetileg változó sajátos funkciók a nagyobb, a jobb földrajzi, geopolitikai elhelyezkedésü településekbe koncentrálódnak, így ezek a települések nemcsak a helybeliek különböző igényeit képesek teljesíteni, hanem a falvakban élökét is. E funkciókat ellátó településeket „,szokás” központi helyeknek, városoknak nevezni. Ezek különböző módon, egyre növekvö mértékben meghatározzák a hatókörükbe eső kisebb, a kevésbé jó pozícióval rendelkező települések, a falvak lehetőségeit. A nagyobb tömeg, az erösebb, egymást is segítő hatalmi tényezỏk, a meglévő kapacitások olyan fejlődési potenciálok, amelyek a további koncentráció alapját is adhatják. A tovább növekvő városok kiemelkednek a városi hierarchiából is, és többszintû́ városi struktúra alakul ki. A fokozatosan koncentrálódó és egyre strukturáltabbá váló településhálózat „elemi szintjén” lévő települések (falvak) és városok között mára egyre inkább elmosódnak a hagyományos különbségek, meghatározó a méret, az elhelyezkedés és a sajátos potenciál, és inkább a betöltött funkcióik különböztetik meg öket egymástól, mint a klasszikus város-falu (foglalkoztatási szerkezet, életmód stb.) kettősség. Csökken az urbánus és a rurális életmód közötti különbség, és új struktúraalkotó elemek jelennek meg. Egyének, családok és társadalmi csoportok determinációja különbözö, fejlödésnek azt nevezhetjük, hogy egyre többen élhetnek a szabad lakó- és munkahelyválasztás lehetőségével.

A történeti fejlödés során már kialakultak azok a központi helyek, amelyek rendelkeznek meghatározó fejlesztési potenciálokkal, ezek empirikus-analitikus megközelítésben leírhatók. Tudatosan, politikai elhatározásból is kijelölhetünk olyan településeket, téregységeket, amelyeknek a jelenleginél több/más feladatot, funkciókat szánunk a térstruktúrában. A gazdaság élénkítését segítő fejlesztéseket meghatározott településekbe koncentrálva növekedési pólusokat és centrumokat hozhatunk létre, amelyektöl azt várjuk, hogy a gazdasági növekedés motorjai legyenek, integrálják környezetuiket, és a fejlödés multiplikátor hatása érzékelhető legyen azok szúkebb és tágabb környezetében is. Vagy/és elvárhatjuk azt is, hogy megfelelö szolgáltatásokkal lássák el természetes vagy adminisztratív körzetüket. Azaz egy kívánatos állapottal vetjük össze a jelenlegi helyzetet, és ennek megfelelóen jelöljük ki a fejlesztések alanyait és azok tartalmát. Természetesen e fejlesztéspolitikai kategóriába tartozó telepủlések is csak a már meglévő fejlödési potenciálok és törvényszerüségek ismeretében jelölhetök ki. A tudatos fejlesztés a meglévő adottságokra épít, de a hiányok kiküszöbölésére, a problémák megoldására és az akkor még nemlétezỏ dolgok létrehozására irányulnak.

A tudatos beavatkozás irányulhat egy-egy beavatkozási területre, településre, de európai, nemzeti és regionális szinten a policentrikus, azaz több-, sokközpontú fejlesztéspolitikát kell követni. A poli- ${ }^{2}$ elötag arra utal, hogy a fejlesztés többirányú, megosztják a funkciókat és a forrásokat a különbözö feladatok és települések között. Ma a szubszidiaritás elve alapján történő decentralizáció hangsúlyozásakor hajlamosak vagyunk a szóösszetételnek csak az elsö tagjára (poli-) koncentrálni, és a centrikus második tagról megfeledkezünk, pedig a központi, a középen levô, a 
Faragó László: A városokra alapozott területpolitika koncepcionális megalapozása.

Tér és Társadalom, 20. 2006. 2. 83-102. $p$

kiemelkedő súlyú és jelentőségủ ugyanolyan fontos. A policentrizmusban, az erre épülö politikában és gyakorlatban nem csak a decentralizáció, hanem a központokra (nem egyre vagy egynéhányra, hanem többre), a meghatározó potenciálokra való koncentrálás, a fejlesztések centrális irányultsága is benne van. A kiegyensúlyozottabb térszerkezet kialakítására irányuló politika, a szubszidiaritás elvének érvényesítése sem tudja megkerülni a (hierarchikus) struktúrákban való gondolkodást, ahol a különböző elemek nagyságrendje, funkciói mások (eltérỏek). Természetesen az egyes elemek minösítésében lényeges különbség lehet. ${ }^{3}$

A városokra koncentráló megközelítés elméleti alapjai több mint száz évre nyúlnak vissza, a policentrikus városfejlesztés számos teória összegzésének tekinthetö.

Marshall $\left(1920^{4}\right)$, a neoklasszikus közgazdaságtan jeles képviselöje felhívta a figyelmet arra, hogy ha több cég, intézmény egy helyre települ, lokálisan koncentrálódik, akkor azok együttlétezése nem csak a belsö gazdaságosságra van hatással, hanem a külső gazdaságosság révén mindenki további haszonra tesz szert. A pozitív lokális externáliák jelentős fejlesztő erők, hatnak a cégek telephelyválasztására és a lokális technológiai extern hatásokból a kis- és közepes vállalkozások is profitálnak. A kritikus tömeg elérése felerösíti, felgyorsítja, beindítja az adott helyen/régióban a fejlödést, ami további növekedést generál. E teória több olasz és angol ipari körzet fejlesztésé$n_{e ́}{ }^{5}$ beigazolódott. $\mathrm{Az}$ ismert esetekben a pozitív külsö externáliák érvényességi területe a napi ingázási körzet, a napi hozzáférési terület (város és környéke).

A christalleri alapgondolat aligha cáfolható: kisebb számú lakosságot ellátó (alap) funkciókat, helyben célszerü és szükséges biztosítani, míg más (ritkábban igénybevett) funkciók, szolgáltatások - az elvárt színvonalon és gazdaságosan - csak nagyobb népesség ellátása esetében valósíthatók meg, így telepítése a központi helyekre (pl. régióközpontokba) ésszerủ. Ennek megfelelően a funkciók száma és „fontossága” szerint a települések funkcionális kategóriákba sorolhatóak. A központi helyek a körzetükbe tartozó településeket is ellátják szolgáltatásokkal. A nagyobb népességet ellátó - funkcionálisan „magasabb szintü” - települések tơbb kisebb népességszámot ellátó, kevesebb funkcióval rendelkező körzetet fednek le. E struktúra szükségszerúen hierarchikusan épül fel, ami gyakran kritikát vált ki a hálózati együttmúködések „híveiböl”. Az „oszthatóság és oszthatatlanság” és a méretgazdaságosság elve is a központi helyek elméletét erösíti.

Minden valóságos településhálózat - így a magyar is - különbözö nagyságú településekböl áll. Könnyen belátható $a z$ is, hogy a magasabb szintủ funkciókat nagyobb népességü településekre célszerủ telepíteni, ezzel lehet az utazási szükségleteket minimalizálni, társadalmi szinten a hatékonyságot növelni. Csak azonos nagyságrendü települések között van értelme azonos szintü funkciókat megosztani. Ha például a Dél-Dunántúlon a regionális funkciókat megosztanák Pécs, Kaposvár és Szekszárd között, akkor a két kisebb városba telepített funkciók igénybevétele utazási/szállítási többletköltségekkel jár(na).

Kétségtelen tény az is, hogy ma már néhány szolgáltatás teljesítése nem jár fizikai mozgással, így ezek bárhová telepíthetők, ahol megfelelő színvonalon el tudják azt látni. Ezekben az esetekben a különbözö szolgáltatást nyújtók fizikai közelsége, 
közvetlen kapcsolattartási lehetösége járhat elönyökkel. A magasabb szintü szolgáltatások profitálnak az egyetemekkel és más hasonló cégekkel való kapcsolattartás lehetőségéből. A már megtelepült szolgáltatások tehetetlenségi nyomatéka, a potenciális munkaeröbázis, a képzés, a többi szolgáltatás igénybevételi lehetőségei és potenciális piaca mind a centrumtelepülések helyzeti elönyét növelik (,kölcsönhatás”, „gazdasági erötér”). Az is a központi helyekre való telepítés, a koncentráció mellett szól, hogy a magasabb szintủ szolgáltatások igénybevétele elöször a fejlettebb központokban jelentkezik, és később terjed lefelé a településhierarchián.

A christalleri gondolatmenetböl az is következik, hogy nem szabad adott népességszámot ellátó szolgáltatások/funkciók további koncentrációját elösegíteni, mert az esetleges mikroökonómiai szintủ nyereséget elviszi a hozzáférési (közlekedési) többletköltség. Az egymással konkuráló szolgáltatások (pl. kereskedelem) esetében számolni kell a ,taszító hatással”, ami ugyancsak erösíti a több helyre való széttelepülést. Tehát ezekben az esetekben a kritikus tömegú fogyasztókra való telepítés kívánatos, ami hasonló fejlesztéseket igényel több településen.

A christalleri modellt sokan bírálták merevsége, túlzott sematizálása miatt, mégis számos településhálózat-fejlesztési politikának, koncepciónak és gyakorlatnak ez az alapja. A kritikák jelentős része abból fakadt, hogy olyan dolgokra is „ráhúzták” e sémát, amire nem alkalmazható. Christaller idejében a gazdasági tér a mezögazdaságot és egyre növekvö mértékben az ipart jelentette. Így az akkori kritika, miszerint az elmélet általánosságban nem igaz az ipartelepítésre, alapvetően ingatta meg az alkalmazhatóságot. De mára a GDP nagyobb hányadát a tercier szektor állítja elö, és e vita további pikantériája, hogy az elmúlt évtizedekben empirikusan is megfigyelhetö, hogy a korszerúbb, magasabb szintű technológiát képviselö vállalatok is a nagyobb, magasabb szintü, kategóriájú településekre koncentrálódnak. A másik gyakori hibaforrás, hogy statikusan kezelik a szintek funkcióit, az azokhoz tartozó szolgáltatási köröket, amikor azok térben és idöben változóak. Nem szabad mereven kezelni a népességkategóriákat és speciális esetekben más ismérveket kell használni (pl. vásárlóerö). Közigazgatási, kereskedelmi, szolgáltatási funkciók elvárt színvonalon történö hatékony teljesitése igazolja a hierarchikus többszintü "központi hely" modellt. De a kváziazonos szintủ központi helyek egy horizontális hálózat elemei is. E többközpontú hálózatok egymásra épülö vertikális rendszereként is felfoghatók. Így a vertikális hierarchia hálózatok hierarchiája, amely lefedheti viszonylag egyenletesen is a teret, illetve hiányok is lehetnek. Ilyenkor a magasabb vagy alacsonyabb háló integráns részei láthatják el a kimaradó szint funkcióit.

A növekedési pólusok elmélete az ötvenes, hatvanas évekig nyúlik vissza (Perroux 1955; Boudeville 1966 stb.). A gyakorlati alkalmazására is ismerünk példákat a világ legkülönbözöbb területeiről, a legkülönbözőbb társadalmi-gazdasági berendezkedésủ országokból. Alkalmazása nem jelenti a központi hely elmélet elvetését. Sőt kiküszöbölheti a christalleri elmélet egyik hiányosságát, nevezetesen hogyan fejlődhet egy település egy magasabb funkcionális szintre, illetve a spontán fejlödés hiátusai tudatos fejlesztéssel miként pótolhatóak. E teória is a marshalli alapokon épitkezik: hipotézise, hogyha elérjük, hogy a különböző gazdasági és 
Faragó László: A városokra alapozott területpolitika koncepcionális megalapozása.

Tér és Társadalom, 20. 2006. 2. 83-102. $p$

A városokra alapozott területpolitika ...

egyéb szereplök egymást erösítö módon hatnak egymásra, akkor az további növekedést indukál. Az újdonságokat (innovációkat) jelentó motorikus egységek igénylik a más gazdasági egységekkel való kooperációt és ezek összessége, nagyságrendük. vezetô pozícióik stb. révén lökésszerủ növekedést indukálhatnak. Ha ez a fejlödés spontán módon nem megy végbe, de a feltételek adottak hozzá, akkor kủlsỏ forrás hozzáadásával megindítható a folyamat, amely multiplikátor hatást fejt ki környezetében. Ismertek a hagyományos ipari vertikumra építỏ ágazati típusú növekedési/fejlesztési pólus teóriák és eszközök és a területi típusúak, anelyek a térbeli közelségre építik a kooperációs lehetöségeket és az ipari tényezőkön kívül kiterjesztik a potenciális együttmúködök körét más szférákra (pl. oktatás, közigazgatás stb.) is. E megközelítés újabb elméletei a területi klaszterek fejlesztésére építenek.

Elsősorban a harmadik világ fejlesztési projektjeiben alkalmazták a „big push” teóriát, amely térben koncentrált több nagy beruházás segítségével kívánt lökést adni a fejlödésnek. Megfelelö nagyságrenddel, kritikus tömeggel és komplexitással próbálták az önfenntarthatóságot biztosítani.

Boudeville (1966) felfogásában a növekedési centrum olyan magas ipari potenciállal rendelkező központi település, ahol a dinamikus ágazatok sokasága van egyszerre jelen, és ezek hatása az egész agglomeráció növekedésére kihat. Sokak szerint a koncentráció természetes folyamat, mert a növekedési centrumok vezérágazatai elsösorban a centrumokban és a környezetükben müködö más tevékenységekre gyakorolnak multiplikátor hatást.

Pottier (1963) nem a növekedési pólusokra, hanem a megfelelö közlekedési kapcsolatokkal rendelkező fejlödési tengelyekre hívta fel a figyelmet. Magyarországon is megfigyelhetö, hogy az autópálya-, autóút-építéseket követte a külföldi múködőtőke- letelepedés, a GDP/fő növekedés és a munkanélküliség csökkentése. Ez felhívja a figyelmet a nagyvárosok közötti és a városok és térségük közti komplex elérhetöség fontosságára.

Myrdal (1957) kumulatív oksági modellel magyarázza hogy bizonyos területeken a növekedés, míg máshol „zsugorodás” megy végbe. (E két jelenség összefüggésben áll egymással.) Gyakori, hogy a centrum „elszívja” a mobil termelési tényezöket a perifériáról és növekedése részben ebböl származik. Ez igaz lehet a főváros és a vidék, a nagyvárosok vagy akár a Balaton és hinterlandja vonatkozásában is. Az áj típusú fejlesztésnél feladat, hogy oly módon induljon be több ponton a fejlödés, hogy a „backwash” hatást minél inkább kiküszöböljük, és a növekedés önjáróvá válását követỏen a városok által integrált területek is fejlödésnek induljanak a „spread" vagy „szivárgási” (Hirschmann) hatás révén.

Krugman (1991) ugyancsak Marsall elméletét elevenítette fel, és bemutatta, hogy a városok növekedése részben a növekvő méretgazdaságosságból (növekvő skálahozadékból) ered. Kísérletet telt a központi hely elmélet és a gazdasági-bázis elméletek integrációjára, és ennek megfelelöen írta le a nemzetkőzi gazdasági folyamatoknak a városrendszerekre gyakorolt hatását. Krugman döntóen makrogazdasági megközelítésben vizsgálta a folyamatokat, és felülról jutott el a regionális klaszterekig. 
Porter (1990) mikroökonómiai megközelítésböl is az agglomerációs elönyöket hangsúlyozza. Rámutatott, hogy a globális piaci szereplök versenyelönyei is az új típusú termelési tényezők földrajzi koncentrációjából, a lokális/területi klaszterekböl táplálkoznak. A különböző gazdasági szereplők és intézmények térbeli sürüsödése, agglomerálódása, a „hazai bázis” az, amely megfelelö hatékonyságot biztosít. Ezek az együttmúködések legtöbbször a nagyvárosokon, azok agglomerációin belüli gazdasági egységek, intézmények közötti kooperációk. Porter ezeket a klasztereket tekinti a mikroökonómia alapegységeinek, és nem az egyes vállalatokat.

A magyar fejlesztéspolitika hatékonyságának javításához integrálnia kellene a fenti regionális gazdaságtani elméletekből azt, ami a megváltozott világban alkalmazható. Az állami beavatkozások területi koncentrációjával, a kritikus tömegek létrehozásával, az agglomerációs elönyök, a pozitív lokális externáliák kihasználásával erösíteni tudjuk a hatékonysági követelmények teljesítését. De a társadalmi és területi kohézió biztosítása érdekében mindezt úgy kell megvalósítanunk, hogy ne sérüljenek a társadalmi és a fenntarthatósági szempontok.

A két szempontrendszer együttes érvényesítése nem könnyủ, hiszen területpolitikai axióma a hatékonyság és méltányosság közötti negatív „trade-off”, azaz adott időben és helyen csak egymás rovására növelhetök. A gyakorlatban a politikai választási lehetőségünk az l. ábrán szemléltetett A és B pontok közötti tartományban van. Ha a szúkösen rendelkezésre álló forrásainkat a gazdasági hatékonysági kritériumok alapján osztjuk meg a különbözö területek/régiók és települések között, akkor a fejlettebb területeken és a nagyobb városokban kell azt koncentráltan befektetni. E stratégiát követik a klasszikus piaci szereplők. A közszférának méltányossági/szolidaritási célokat is teljesítenie kell, még annak tudatában is, hogy ha a hátrányos helyzetủ elmaradott területeket, a kicsi, önmagukban versenyképtelen településeket támogatja, akkor csökken a források felhasználásának a hatékonysága, és a folyamatok önfenntartó képessége is kérdéses lehet. De napjaink aktuális kérdése éppen az, hogy miként tudnák mindkét kritériumrendszert együttesen érvényesíteni. Az EU számára is nagy kihívás a versenyképességról, a hatékonyság emeléséról szóló Lisszaboni Stratégia összeegyeztetése a göteborgi célokkal és a társadalmi-gazdasági-terulleti kohézióval. Az Unió vagy bármely ország úgy is elósegítheti a nagyobb növekedést és a több munkahely teremtését, hogy a kevésbé fejlett területeken, minden megfelelö potenciállal rendelkezö településen új fejlödést generál, új munkahelyeket hoz létre. Ehhez a ,pentagonon” kívül új globális integrációs zónákat kell kialakítani (pl. Közép-Európában) és revitalizálni kell a kis és közepes városok hálózatát. Magyarországon pedig területileg kiegyensúlyozottabb, többpólusú, a fenntarthatóság szempontjait is figyelembe vevö területpolitikát kell megvalósítunk (1. ábrán az alászínezett tartomány), azaz, ha a városok húzó erejére alapozva dinamizáljuk az elmaradott területek forrásait, akkor nemcsak a gazdasági összteljesítmény nő (több munkahely, nagyobb GDP), hanem egyúttal a társadalmi, a gazdasági és a területi kohéziót is erösítjük. 
Faragó László: A városokra alapozott területpolitika koncepcionális megalapozása.

Tér és Társadalom, 20. 2006. 2. 83-102. $p$

TÉT XX. évf. 2006 — 2

A városokra alapozott területpolitika ...

91

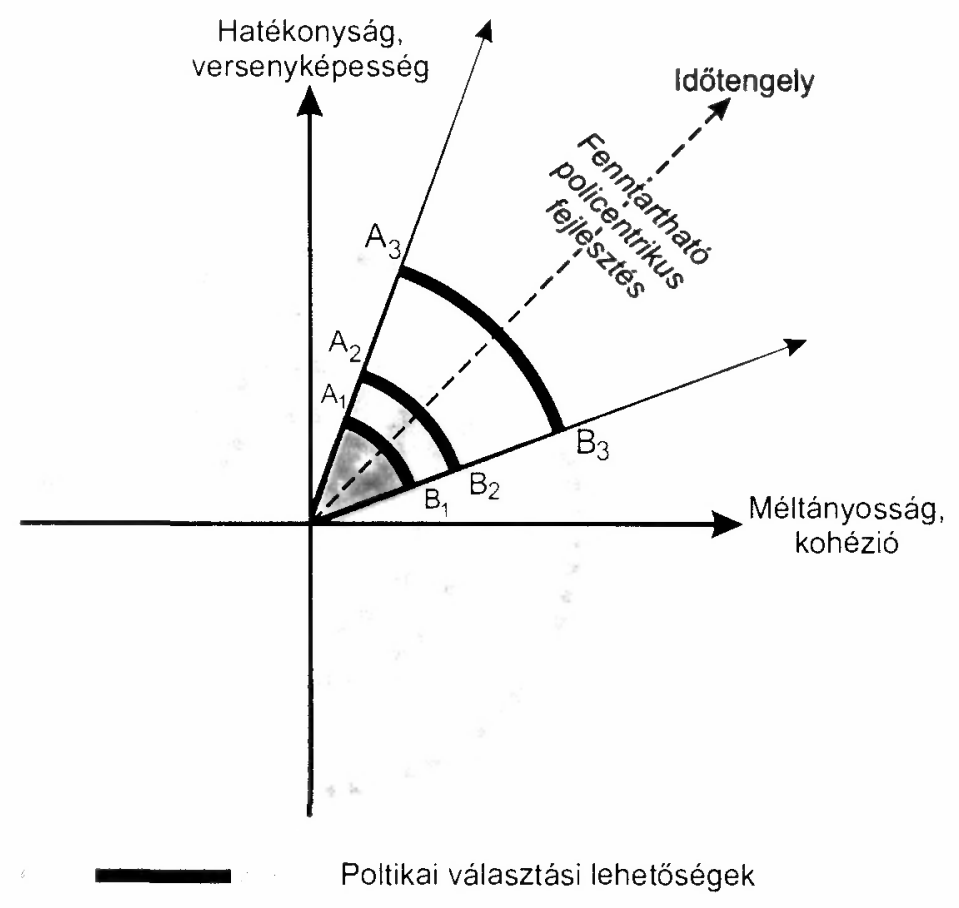

Forrás: Saját szerkesztés.

\section{Hangsúlyváltás az Európai Unióban}

A policentrizmus gondolatát már az 1950-es, 1960-as években megtaláljuk az európai országok településhálózat-fejlesztési gyakorlatában is. A francia „métropoles d'équlibre" koncepció a nemzeti szintủ gazdasági kiegyenlítés és a föváros túlsúlyának a mérséklését tartalmazta. A holland városfejlesztési gyakorlat több nagyváros funkciómegosztására és kooperálására épít(ett). Svédország is átesett a közigazgatási reformon, lokális szinten koncentráltak, majd azok központi helyeire decentralizáltak állami funkciókat. És sorolhatnám a nemzeti politikákat. Az Európai Unióban a policentrikus fejlesztés az 1990-es években jelent meg. A Lipcsei Irányelvek (1994), majd a holland elnökség alatt kiadott ESDP első változata (Noordwijk 1997) már tartalmazza, mint területpolitikai célkitủzést. A potsdami hivatalos változatnak már fontos a politikai üzenete, bár részletes kifejtése nem történt meg. Az $\mathrm{ESPON}^{6}$ program már explicit módon kutatja a policentrikus fejlődés sajátosságait 
és lehetöségeit. A Lisszaboni Stratégia megvalósítása szükségszerüen a városokra koncentrál, ahol ma már a hozzáadott érték több mint 90\%-a termelödik. A CEMAT 2004-es rotterdami tanácskozásán kiemelték a városok szerepét a kohéziós politikában. Az Európai Parlament az „Európai Unió bỏvítésének városi vonatkozásairól" szóló jelentésében (EP 2005/0272) üdvözölte a városfejlesztés integrálását a kohéziós politikába és a hatókörébe tartozó alapok felhasználásába. 2005-ben a Bizottság egy munkaanyagot indított vitára „Kohéziós politika és a városok: a városok hozzájárulása a régiók növekedéséhez és a foglalkoztatási helyzethez" címmel. E dokumentumban nem csak a városok fontosságát hangsúlyozzák, hanem a teendőkre vonatkozó iránymutatásokat is megfogalmaznak! „A versenyképességgel kapcsolatos sok kérdés regionális és nemzeti ügy, amelyben gyakran a regionális fejlesztési ügynökségek vállalják a vezető szerepet. Azonban számos kérdésben a helyi hatóságoknak is fontos szerep juthat. ... A szóban forgó kérdésektől függően egyre inkább helyi vagy akár városrész szintü megközelítésre van szükség. ... A tagállamokat bátorítani kell arra, hogy a városi kérdések megoldására a Strukturális Alapok operatív programjainak keretében célzottan adjanak pénzeszközöket a városoknak. A partneri kapcsolat összes elönyének a kihasználása érdekében a városoknak kell a felelösöknek lenniük, beleértve az alprogramok tervezésének és megvalósításának a felelöségét is." Ennek megfelelöen a Strukturális Alapokat szabályozó rendeletek lehetővé teszik, hogy a városokat érintô intézkedéseket helyi szintre delegálják. Mindezek eredményeként egyre kevesebbet halljuk a „régiók Európája” szlogent és egyre nagyobb hangsúly helyezödik a versenyképesség erösítésének, a gazdasági növekedésnek a motorjaira, a városokra, a városrégiókra, azok policentrikus hálózataira.

A területfejlesztés, a területi tervezés nem EU Bizottsági hatáskör, de az ESDP-t mégis egyre többen érvényesítik a nemzeti területpolitikában, és az EU kohéziós politikája is egyre komolyabban veszi a területi dimenziót. Az Amszterdami Szerződésben megjelent és az alkotmánytervezetben is szereplö „területi kohézió" fogalma (gazdasági, társadalmi kohézió mellett a 3. elem) egyre inkább lefedi a mi szóhasználatunk szerinti területfejlesztést. A különböző területekre készült egységes politikák, tervek integrálni tudják a különböző (ágazati, funkcionális, területi) megközelítéseket, képesek kihasználni a lehetséges szinergiákat. Ameddig nem változik az uniós álláspont és szabályozás, addig elsősorban a nemzetállamok (területfejlesztésért felelös miniszterek) felelössége, hogy miként kezelik az uniós és a hazai politikák térségi hatásait.

2005 májusában az Unió illetékes miniszterei elfogadták „Az Európai Unió területi helyzete és távlatai" (TSP) címủ dokumentum készítésének elveit. ${ }^{8}$ Ennek alapján a tagállamok bevonásával 2007-re készül el a végleges anyag. Ez nem egyszerủen egy új ESDP lesz, hanem operatívabb iránymutatásokkal szándékozik segíteni a lisszaboni és göteborgi célok teljesítését. A TSP „scoping” dokumentumának (2005. III. és 13. o.) az első két prioritása a következő:

1. Az európai fejlődés motorjait jelentő agglomerációk, városok és városhálózatok térségi politikájának ösztönzése. 
Faragó László: A városokra alapozott területpolitika koncepcionális megalapozása.

Tér és Társadalom, 20. 2006. 2. 83-102. $p$

2. A város-vidék partnerség megszilárdítása és közérdekủ szolgáltatások megfelelö szintjẻnek biztosítása a kiegyensúlyozottabb területi fejlödés érdekében.

A TSP elsỏ nem hivatalos egyeztetési változatának ${ }^{9}$ perspektívák kialakításáról szóló $\mathrm{C}$ fejezete az alábbiakat fogalmazza meg a városi régiók és nagyvárosok vonatkozásában $(61.0$.$) :$

- Az európai magtérségeken kívül számos olyan nagyvárosi térséget találunk, amelyeket meg kell erősíteni annak érdekében, hogy jobban kiaknázhassák a térségi potenciálokat és csökkenthessék a meglévő egyenlötlenségeket, amely végső soron az európai térség harmonikusabb és policentrikusabb fejlödését segíti elö.

- A nagyvárosi térségeken kívül eső városok a növekedés motorjai, és mint ilyenek, fontos kisugárzó hatással bírnak környezetükre (a speciális funkciók nemzetközi központjaitól az általános szolgáltatásig és a vidéki fejlesztési pólusokig).

- A nagyvárosi és városi térségek akkor lehetnek erősebbek és versenyképesebbek, ha jobban koncentrálnak saját profiljuk fejlesztésére.

- A belső városi kihívásokat megfelelően kell kezelni, annak érdekében, hogy a negatív agglomerációs hatás ne gátolja a nagyvárosi és városi térségek helyi potenciáljainak kiaknázását, és ne csökkentsék azok vonzerejét a befektetök és a lakosság szemében.

(Meg kell jegyezzem, hogy európai szintről nézve, az ESPON tipológiának megfelelően Magyarországon csak egy nagyvárosi térség van, Budapest és környéke.)

Ugyanebben a dokumentumban a vidéki sokszinüség fenntartásával kapcsolatos politikai megfontolásként az alábbiakat olvashatjuk:

- Európa jelentös része vidéki térség, és még mindig rengeteg ember él vidéken. Sajnos azonban az ilyen térségek aránytalanul kisebb GDP-t termelnek, ugyanis nem használják ki kellőképpen a helyi potenciálokat.

- A városi területekhez közel eső vidéki térségek népességgyarapodás és gazdasági fejlődés tekintetében profitálhatnak a közelségböl, de egyúttal a városi terjeszkedésből és a városi és vidéki földhasználati igények ellentéteiböl fakadó kihívásokkal is szembe kell nézniük.

- A távoli, vidéki térségeket a népességcsökkenés fenyegeti, és további veszély, hogy nem képesek az alapvető közszolgáltatások biztosítására.

- A vidéki térségekben egyre nő a forgalom, ugyanakkor a másodlagos hálózatok gyakran nem képesek a forgalom levezetésére, fổleg az Európai Unió keleti felében.

- A növekvő energiaárak és az abból fakađó szállítási/közlekedési költségek elsősorban a vidéki térségeket érintik. Ugyanakkor éppen ezek a térségek használhatják ki jobban az alternativ energiaforrások adta lehetőségeket.

- Hosszú távon konfliktus léphet fel az élelmiszer-termelés és az alternatív energiaforrások termeléséhez szükséges földhasználat között. 
Faragó László: A városokra alapozott területpolitika koncepcionális megalapozása.

Tér és Társadalom, 20. 2006. 2. 83-102. p

- A vállalkozói kedv ösztönzése kedvezően hat a vidéki térségek gazdasági bázisának diverzifikációjára, a helyi hálózatok kiépítésére és a megfelelö kompetenciákkal rendelkező hatóságok megalakulására.

A magyar Nemzeti Stratégiai Referenciakeret (2007-2013) tervezetéról az Európai Bizottsággal történt informális tárgyalásokon Brüsszel részéról hangsúlyozták, hogy minden ágazati beavatkozás, illetve operatív program esetében is meg kell jeleníteni annak területi/regionális dimenzióját! Azt is világossá tették, hogy a regionális szintü megközelítés fókuszában is a városias terïletek vannak, és az integrációnak kell rurális területekre irányulniuk (gazdasági diverzifikáció és a helyi közösségek támogatása). Megértéssel nyugtázták, hogy a regionális növekedési pólusok fontos szerepet kapnak a $\mathrm{K}+\mathrm{F}$ fejlesztésekben.

Összességében megállapítható, hogy a gazdasági szükségszerüségekre hivatkozva egyre nagyobb szerepet kap a Lisszaboni Stratégia teljesítése, így e folyamat maga alá gyüri a kohéziós politikát és eszközrendszerét is. A Strukturális és Kohéziós Alapokat igénybevevő országokat és régiókat a támogatási rendszeren keresztül szabályozási eszközökkel „rákényszerítik” az új szempontok nemzeti politikákba (tervekbe) való illesztésére. A régiók szerepnövekedése megállt, és a városfejlesztési szempontokat integrálni kell a nemzeti és a regionális tervekbe. Az ESDP alapelveinek a lisszaboni célkitüzések tükrében való újragondolása várhatóan az alábbi stratégiai célkitüzéseket eredményezik:

- A hangsúly a policentrikus városfejlesztésre helyezödik, amely elsősorban a fejlődési potenciálokkal rendelkező városok és hálózataik fejlesztését jelenti.

- Biztosítani kell a központok elérhetőségét és javítani kell a térségi integrációt.

- Fenntartható város-vidék kapcsolatot kell kialakítani és erösíteni.

Fel kell hívnunk a figyelmet arra, hogy a gazdasági növekedés, a munkahelyteremtés is sikeresebb lehet, ha Európa kihasználja a különbözö területegységek (pl. Közép-Európa, Délkelet-Európa stb.) országok sajátosságait és igényeit. Több monocentrikus országban csak úgy valósítható meg a policentrikus fejlesztés, az ország egésze csak úgy képes hozzájárulni a közös célok teljesítéséhez, ha nem csak az európai nagyvárosokat vonjuk be e folyamatba, hanem a nemzeti/nemzetközi funkciókat betölteni képes közepes és kisvárosok, azok hálózatai is jelentös szerepet kapnak, és ezzel egy időben sikerül megoldania a rurális térségek integrációját!

\section{Mozaikok a magyar elötörténetböl}

Sokan sokáig nem választották el a területi és a települési megközelítést. Az elmúlt száz évben a városokat és azok területi/regionális funkcióit általában együtt értelmezték, a városias centrumokat és a hozzá tartozó vidéket együtt kezelték. Söt, gyakran ha bármilyen szintủ területi felosztásban gondolkodtak, akkor először a központokat keresték meg, majd a hozzájuk tartozó területet. Mindig azoknak az országrészeknek, azoknak a körzeteknek a lehatárolása, hovatartozása okozott gondot, azokról folyt vita, ahol nem volt megfelelő súlyú központi település. Megfelelő köz- 
ponti hely nélkül ide-oda kallódtak területek. Minden vidéknek legyen városa, fogalmazta meg Erdei (1939/74). Gyakran még az országrész megjelölése is a központi város nevét viselte: miskolci, debreceni, szegedi körzet/régió stb. A nagyrégiók központjai között Budapesten kívül mindig ott volt az „öt nagy”, és csak arról folytak viták, hogy ki kell-e egészíteni a kört, és mely városokkal. Ugyanazok az országrészek (megyék) hovatartozása és a városok megnevezése volt bizonytalan, mint ma. Több vitában, koncepcióban és tervben Nyugat-Magyarországon Nagykanizsa vagy Szombathely merült fel és Belső-Magyarországon Székesfehérvár és Szolnok. De ezek kapcsán soha nem alakult ki olyan konszenzus, mint az öt nagyváros esetében.

A két világháború között például Hantos (1931) hét régiót jelölt ki az általa „természetesnek" nevezett központokkal (Budapest, Györ, Szombathely, Pécs, Szeged, Debrecen és Miskolc). Erdei a II. világháborút megelőzően a városok fejlesztését hangsúlyozta, és kitüntetett szerepet szánt a regionális központoknak.

1958-ban egy kormányhatározat (2030/1958. IV. 15.) alapján a tervezést kilenc nagy régióban és azokon belül a városi vonzáskörzetekben képzelték el. Régióközpont a fövároson és az öt kiemelt nagyvároson kívül Székesfehérvăr, Nagykanizsa és Szolnok volt.

1963-ra elkészült a VÁTI-ban az ország első átfogó területi terve. Ezt 1965-ben adták közre Magyarország Településhálózat-fejlesztési Tanulmányterve címen. A tanulmány három központi (budapesti, szolnoki és székesfehérvári) és hat periférikus régiót (miskolci, debreceni, szegedi, pécsi, nagykanizsai, és győri) jelölt ki. A szakmai és társadalmi vita alapján az eredeti terv módosításra került, és 1968-ra készült el az újabb változat, amelyet Országos Településhálózat-fejlesztési Kerettervnek neveztek el.

Erdei (1931/1971) a települések, a városok rendszerét egy csillagászati hasonlattal érzékeltette. A világ településrendszere a csillagrendszerhez, az országoké a naprendszerhez hasonlít. Magyarország „napja” a föváros, föbolygói az öt nagyváros. Ezek a vidéki nagyvárosok ellenpólusoknak vagy melléknapoknak is tekinthetök. A többi vidéki văros ezek albolygói, és azok vonzáskörzetében helyezkednek el az egyéb települések, a holdak. E leírásban például Szeged „ellenpólus-văros, melléknap, dél-alföldi föbolygó vagy Dél-Alföld regionális szerepkörủ városa - mindegy, hogyan nevezzük, ezek értelme lényegében ugyanaz: ezen a nagyobb területen központi hely, és a vonzáskörzetében tartja szélesebb vidékét" (Erdei 1971, 19). Szeged körül négy különbözö nagyságú vonzáskörzetet különböztetett meg: közvetlen városkörnyék, járás (ma kistérség), megye és országrész/régió (három megye). E rendszerben Szeged napja/fövárosa Budapest, és azonos szintü szomszédos bolygója/városa Debrecen és Pécs felsőfokú központok. Szegedhez hasonlóan elemezte az „albolygókat” (Hódmezővásárhely, Szentes, Makó és Csongrád) és azok egyedi tereit, vonzáskörzeteit. Vizsgálatainak tanulságait az alábbi következtetésekben foglalta össze:

- Minden település, településrendszer egyedi, a történelem egy-egy konkrét darabja.

- Ezek az egyedi esetek általános törvényszerüségek alá esnek. 
- Idỏröl időre fel kell oldanunk azt az ellentmondást, hogy a településrendszert nem lehet sémákba szorítani, de a normális müködés érdekében mégis kategóriákat kell alkotnunk. „Kétszeres izgalom vár tehát arra, aki belemerül egy-egy adott terület történelmi valóságába. Érzékelheti a konkrét egyedi jelenségek különleges ízét, színeit és izgalmas érdekes kombinációit; ugyanakkor mindezek mögött általánosan ható törvényszerủségek érvényesülését foghatja fel" (Erdei 1971, 25).

Többek között e gondolatok formalizálására és gyakorlatba való átültetésére vállalkoztak a politikusok és a tervezök 1971 -ben, amikor megalkották a területfejlesztés irányelveirôl (1006/1971. [III. 16.] Korm. hat.) és az Ország Településhálózat Fejlesztési Koncepciójáról (1007/1971. [III. 16.] Korm. hat.) szóló kormányrendeleteket. A településhierarchiának megfelelően öt kategória fejlesztésére határoztak meg irányelveket:

1. Budapest: A főváros túlfejlett, ebből következően át kell tekinteni a további fejlesztését és szelektív iparfejlesztésre kell törekedni.

2. Nagyvárosok: Olyan fejlesztési súlypontokat kell kijelölni, ahová a fejlett technikát telepíteni lehet.

3. Kis-és középvárosok: A növekedés infrastrukturális feltételeit kell megteremteni.

4. Faluhálózat: A településhálózatnak igazodni kell a mezögazdaság csökkenő foglalkoztatásához. Ki kell jelölni a centrumközségeket.

5. Tanyavilág: megszünését sem siettetni, sem lassítani nem szabad.

Az 1971-es OTK a településeket az elvárt központi funkcióik (szolgáltatások) szerint sorolta hierarchikus rendbe, ami elöre vetítette a központok fejlesztésére, a hiányzó kapacitások pótlására irányuló fejlesztéspolitikát és gyakorlatot.

a) országos központ (népessége az agglomerációval együtt 2,6-2,8 millió fö);

b) felsöfokú központ

- kiemelt felsőfokú központ (150-300 ezer, vonzáskörzetükkel együtt 1,0-1,5 millió fö),

- felsőfokú központ (80-150 ezer, vonzáskörzetükkel 400-600 ezer fỏ),

- részleges felsőfokú központ 50-60 ezer, vonzáskörzetükkel 150-400 ezer fö,

c) középfokú központ (20-40 ezer, vonzáskörzetükkel 50-120 ezer fö);

- részleges középfokú központ: (8-15 ezer, vonzáskörzetükkel 20-25 ezer fö),

d) alsófokú központ

- kiemelt alsófokú központ (5-10 ezer, vonzáskörzetükkel 10-15 ezer fö),

- alsófokú központ (3-4 ezer, vonzáskörzetükkel 5-6 ezer fö)

- részleges alsófokú központ (1-2 ezer, vonzáskörzetükkel 2-3 ezer fö)

e) egyéb települések.

A fỏváros és az öt kiemelt felsőfokú központ körül hat tervezési gazdasági körzetet/régiót is kialakítottak, de az ezekre megkezdett tervezést 1973-ban abbahagyták. 
Faragó László: A városokra alapozott területpolitika koncepcionális megalapozása.

Tér és Társadalom, 20. 2006. 2. 83-102. $p$

TÉT XX. évf. 2006 @ 2

A városokra alapozort területpolitika ...

97

Az 1971 -es OTK - kétségtelen erényei ellenére ${ }^{10}$ - rengeteg vitát váltott ki. Ezek elsödleges oka az volt, hogy a terv eredeti szándékával ellentétben a lobbyzások hivatkozási alapjává vált. Ráadásul a szűkös forrásokból először a magasabb szinten hiányzó intézményeket kezdték pótolni, így „,ellázadtak” az alsóbb szinteken élők, mert joggal féltek attól, hogy számukra már nem marad megszerezhető fejlesztési forrás. Ugyancsak sokan kifogásolták az erős vertikális hierarchiát, a fentről lefelé logikát/gondolkodást. A mai vitákon sokan érezhetik úgy, mintha ugyanazok az érvek és ellenérvek hangoznának el, mint harminc évvel ezelött.

Részben az 1971-es OTK hibáinak korrigálását tủzte ki célul az 1979 és 1982 között készült Országos Területrendezési Terv (OTT). Ebben oldani kívánták a merev vertikális hierarchiát, urbanizációs tengelyeket jelöltek ki, az egyéb településeket a településhálózat alapjaiként kezelték, megszüntették a merev népességkategóriákat stb. A sokkötetes munka megyei és minisztériumi egyeztetését megkezdték, de jóváhagyásra, elfogadásra sosem került. A munka egyetlen kézzelfogható eredménye egy minisztertanácsi határozat volt (1018/1981. VI. 19.), amely az 1971-es OTK leginkább kifogásolt elemeit módosította.

1985-ben az Országgyülés határozatot hozott (12/1980-1985.) a terület és településfejlesztés hosszú távú irányelveiröl. A határozatban foglalt viszonylag korszerủ elvek gyakorlati érvényesítése nem történt meg.

Magyarországon a rendszerváltást követően a területpolitika meghatározó szemléleti alapja a területi/regionális " megközelítés volt. Ezen belül a rurális/vidékies területek kerülttek kiemelésre, és ezek fejlesztése nagyobb hangsúlyt kapott, mint az urbánus/városias területeké. A gyakorlatban a tervezés, a források elosztása felülröl lefelé történt, és a lentről felfelé irányt a konkrét (ágazati) projektek gyüjtése és centralizált szelektálása jelentette. Így az országos/nemzeti területpolitikában „elvesztek” a telepuilések, a városok. Az elmúlt 16 évben nem volt és még ma sincs kormányzati városhálózat-fejlesztési politika és gyakorlat. Ennek okai többek között:

- Az uniós integráció „main stream”-mé emelte a regionalizmust és a Közös Agrárpolitika reformkísérletei, valamint a magyar agrárium központi irányításának kiüresedése felértékelte a vidékfejlesztést.

- A kilencvenes évek elejétől a hazai szakma (beleértve az MTA RKK-t is) a régiók és a kistérségek szükségszerü kialakítására és megerösítésére koncentrált.

- Az önkormányzati törvényből adódóan sokan a településfejlesztést kizárólag önkormányzati hatáskörnek tekintették. Az önkormányzatok őrködtek önáłlóságuk, ,döntési szabadságuk” megörzése felett. Bár e szabadság csak jelképes (volt), mert a források csaknem egésze a müködtetésre, a fenntartásra ment el, és strukturális lépésekre, fejlesztésekre jó esetben is csak a saját vagyon eladásából jutott.

- A területfejlesztés téves értelmezése és szabályozása. Még ma is sokszor találkozhatunk - szerintem téves - szemlélettel, miszerint a településfejlesztés a területfejlesztés komplementere. ${ }^{12}$ Az 1996. évi területfejlesztési törvény kivette a területfejlesztés hatásköréböl a településfejlesztést, ${ }^{13}$ így hatályos törvényi szabályozás alapján készuilt dokumentumok (koncepciók, stratégiák, 
Faragó László: A városokra alapozott területpolitika koncepcionális megalapozása.

Tér és Társadalom, 20. 2006. 2. 83-102. $p$

rendezési tervek) nem foglalkoztak vagy csak érintölegesen a településhálózattal, a településfejlesztéssel.

- Kompetens és cselekvőképes központi intézmény hiánya. A minisztériumi, hivatali struktúrából hiányzott a város (hálózat)fejlesztésért felelős intézmény. 1990-től 2006-ig a településfejlesztés a Belügyminisztérium hatáskörébe tartozott, amely nem „fejlesztési típusú és orientáltságú” tárca volt. A hatáskörmegosztás status quójának megfelelően a területfejlesztésért felelős intézményekben sem volt a településfejlesztésért (városfejlesztésért, falufejlesztésért) felelős szervezeti egység (főosztály, osztály).

- A rendszerváltást követően a falvak városellenes hangụlata ${ }^{14}$ és a városok befelé fordulása.

Az 1998-as Országos Területfejlesztési Koncepció (OGY-határozat) alig foglalkozott a városfejlesztéssel. A policentrikus városfejlesztés, mint központi politikai opció csupán jelzésszerüen szerepel a dokumentumokban. A határozatban megfogalmazott irányelvek között találhatjuk az erre vonatkozó utalást: „a túlzott Budapest központú térszerkezet oldása a növekedésre alkalmas központok fejlesztésével". E tétel kifejtésére (a központok nevesítésére stb.) és az ebből eredő gyakorlati teendők megfogalmazására nem került sor. Fejlesztési célokat és prioritásokat döntő mértékben térségtípusonkẻnt (hátrányos helyzetủ, ipari szerkezetátalakítással érintett térségek stb.) és ágazatonként (környezetvédelem, idegenforgalom stb.) jelölte ki. Az OGY határozat bővebb háttéranyaga is csak minimálisan érinti a városfejlesztést. ${ }^{15}$

Az új, 2005-ben elfogadott OTK (97/2005. OGY-határozat) esetében már javult a helyzet, a dokumentum egyaránt tükröz térségi és településhálózat-fejlesztési szemléletet is. A 2013-ig megfogalmazott országos célok között szerepel a „versenyképes budapesti metropolisz-térség” és a „régiókat dinamizáló fejlesztési pólusok megerősítése és a városhálózati kapcsolatrendszer fejlesztése". Az OGY határozat melléklete már tartalmaz koncepcionális térképet is a regionális pólusokról és tengelyekröl. Ugyancsak a mellékletben már találunk a városokra vonatkozó részcélokat is.

A parlament által határozati formában elfogadott dokumentumok fejlesztö ereje, szabályozási, elóíró státusza kétséges, ${ }^{16}$ és hatásuk is lényegesen elmarad az 1971es elődjükétöl. Egyrészt nem kötelez senkit semmire, így irányelvszerü, másrészt nagyon szükszavú. Mindkét OGY-határozat háttéranyaga/melléklete lényegesen bővebb, de az ebben foglaltak csak az értelmezést segítik vagy legfeljebb ,jó tanácsokat ad". Ezért fontos, hogy azok miként épülnek be az egyéb fejlesztéspolitikai dokumentumba. De lényegi hiányossága mindkét OTK-nak, hogy egyik sem vállalja fel a regionális központok és növekedési pólusok megnevezését és azok „koncentrált" fejlesztését.

A II. NFT (NSRK) tervezete alapján az alábbi fő megállapításokat tehetjük:

- Az OTK-ra és az OFK-ra alapozva kísérletet tesz a regionális és a telepuiléshálózati megközelítés integrálására, de azt nem viszi következetesen végig a terven.

- A policentrikus városfejlesztés nem explicit és következetes fejlesztési irány. 
Faragó László: A városokra alapozott területpolitika koncepcionális megalapozása.

Tér és Társadalom, 20. 2006. 2. 83-102. $p$

- Nem kerülnek hangsúlyosan megnevezésre a támogatásra szoruló elmaradott szerkezetátalakítással küzdỏ területek és a növekedési potenciállal rendelkező területek és városok, amelyek hajtóerỏi lehetnek a fejlődésnek.

- A végrehajtás intézményrendszere a végletekig centralizált, nem szolgálja a regionalizációt és nem erősíti a nagyvárosok önállóságát.

\section{Az új(, ,retro") területpolitika lehetséges alapelvei}

Divat a „retro”, a hatvanas hetvenes évek dizájnja, az öltözködésben, a lakberendezésben, a zenében stb.. A területpolitikában is újra napirendre kerülnek korábbi kérdések, de nem divatból, hanem mert mind a mai napig nem adtunk korrekt választ a felvetett kérdésekre, alaptalanul feledésbe merültek időtálló elvek, megállapítások, és múlandó politikai megfontolások feliilírták a ,józan észt". Így nem csoda, hogy Bibó hetvenes években írt szavai igencsak aktuálisak: „Magyarországon e pillanatban a településhálózat $\mathrm{s}$ benne a városhálózat fejlesztése elsőrendü fontosságúnak és aktuálisnak tekintett jelentős kérdés .... Csupán annyi történt, hogy a legutóbbi években mind nagyobb mértékben érezhetôvé vált az országos tervezés számára a megyénél nagyobb egységek szüikségessége..." (Bibó 1986, 143).

Számos régi és egyben nagyon is aktuális területpolitikai kérdésre kell választ adnunk. Újra kell értékelni a területfejlesztés ,hatáskörét és feladatait” és vissza kell állítanunk a belső egyensúlyát. A lisszaboni célok teljesítését a jövőben is ki kell egészíteni „,hagyományos” területi törekvésekkel, hiszen az elmaradott térségekben a versenyképesség megteremtésének az alapja a felzárkóztatás, tehát a hatékonysági kritériumok teljesíthetőségéhez szolidaritási alapon meg kell teremteni a szükséges elöfeltételeket. A régiók és a kistérségek közötti különbségek mérséklésének is kulcsszereplöi a városok, a városrégiók. A különbözö terïleti szintek között világos feladat- és funkciómegosztást kell kialakítani, ami decentralizációval és az alsóbb szintekről az állam kivonulásával kell járnia. Újra kellene szintetizálni a városfejlesztési és a regionális fejlesztési modelleket és új minőségü területpolitikát, területfejlesztési logikát kellene alkalmazni, amelyben a városoknak kiemelkedő szerepük van.

A megújuló gazdaságpolitika területi elvei többek között az alábbiak lehetnek:

- $\mathrm{Az}$ adminisztratív megyék és régiók gazdaságilag nagyon heterogének, a klaszterképzéshez, a gazdasági kooperációkhoz túl merev egységek. Az állandóan változó területi egységekre kiterjedő gazdasági folyamatok is a nyitott terek csomópontjaiból irányíthatók, a hálózatszerủ mủködés onnan szervezhetô.

- A gazdaságpolitikának a fejlödés hajtóeröire, a (gazdasági) pólusokra kell koncentrálni. Ma az elsődleges fejlesztő erő a tudás, az innovációk $(\mathrm{K}+\mathrm{F}$, egyetemek, IKT-szektor stb.), amelyek termelésében és terjesztésében a városoknak (nem csak régióközpontoknak) döntô szerepük van.

- A versenyképesség javítása, a versenyszabályok betartása és a korrupció elkerülése érdekében, nem az egyes vállalatokat, konkrét szereplöket kell/lehet támogatni, hanem a minden piaci szereplö számára elérhető gazdasági környezetet, 
miliöt kell fejleszteni. A közszféra elsödleges beavatkozási területe a pozitív külsö hatások lehetövé tétele és a negatív externáliák esélyének csökkentése.

- Kritikus tömeget kell létrehozni, megfelelő nagyságrendü csomópontok hálózatát kell kiépíteni, amely területileg koncentrált fejlesztést jelent.

- Mindebből az következik, hogy az állami gazdaságpolitikának a fejlödési potenciállal rendelkező központokat/városokat kell fejleszteni, és elö kell segíteni, hogy a városokból (a gazdasági pólusokból, centrumokból) kiinduló növekedés/innováció a piaci kapcsolatokon keresztül hasson a térségükre.

Az új/retro területpolitika alapelveinek a következöket javaslom:

- A térstruktúra építő kövei, a fejlesztéspolitika alapegységei a funkcionális városi körzetek, a városrégiók. Elö kell segíteni, hogy a „központi helyek” (gazdaságilag) integrálni tudják körzetük/régiójuk településeit.

- A központok/városok kiemelt fejlesztésével párhuzamosan az elérhetőségüket is biztosítani kell, ezért az elérhetöség, vagy szélesebb értelemben az információhoz, szolgáltatásokhoz való hozzáférés biztosítása ugyanazon politika másik oldala.

- Budapestet az európai metropoliszhálózatban és a Kárpát-medencében betöltendö szerepkörének megfelelöen kell fejleszteni. A föváros országon belüli dominanciájának mérséklése, a zsúfoltságának elkerülése érdekében policentrikus területpolitikát kell folytatni, ki kell jelölni a regionális központokat és alkalmassá kell tenni öket regionális feladataik ellátására, és erösíteni kell a városhálózat többi elemét is. Budapest is csak úgy lesz képes nemzetközi szerepkörét betölteni, ha fejlödő ország fővárosa és erős városhálózatra támaszkodhat.

- A regionális központok Magyarországon periférikus fek vésủek, de ez alkalmassá teheti azokat nemzetközi szerepkör betöltésére. Az európai léptékben kis tömegükből, korlátozott kiterjedésú vonzáskörzetükből fakadó hátrányukat néhány funkciójuk erőteljes fejlesztésével, országos, esetleg nemzetközi jelentöségüvé tételével lehet részben ellensúlyozni. Ha központi támogatásokkal nem lesznek képesek e települések lépéselönyre szert tenni, akkor a határ túloldalán lévő jelentős városok dominanciája fog érvényesülni.

- Új város és vidéke (körzete/régiója) modell kialakítása szükséges: a rurbanizációt kell támogatni, a falvakat a térségi funkciómegosztásba kell integrálni.

- A központi államigazgatásban ki kell alakítani a városfejlesztési politika és fejlesztés gazdáját. Egy szervezeti egységbe kell integrálni a településfejlesztést és -rendezést. A területfejlesztési döntési mechanizmusokban is súlyuknak megfelelö szerepet kell hogy kapjanak a városok.

- Az NSRK (ÚMP) alapvetö területi dimenziója, célterülete a régió, de meghatározó elemévé kell tenni a policentrikus városfejlesztést is. Feladat a városfejlesztés explicit megjelenítése az OP-kban és a majdan készülö akciótervekben. A fontosabb magyar (nagy)városi programokat is be kell integ- 
Faragó László: A városokra alapozott területpolitika koncepcionális megalapozása.

Tér és Társadalom, 20. 2006. 2. 83-102. $p$

TÉT XX. évf. 2006 - 2

A városokra alapozott területpolitika ...

101

rálni a nemzeti fejlesztési programokba, és a városi hatóságokat közvetlenül be kell vonni a lebonyolításba (pl. közremüködö szervezetek)!

- Erösíteni kell a területi és településhálózati megközelítés integrálását.

- A városokra alapozott új területpolitika megvalósítására összehangolt cselekvésre, intézkedéscsomagra van szükség. Az OTK-ban és az uniós tervekben megfogalmazott városi feladatok teljesítésére új múködési szervezeti modellt kell kialakítani.

- A területfejlesztési és -rendezési dokumentumokba integrálni kell a településfejlesztést és a településhálózat-fejlesztést. Ez utóbbi - az új város-falu kapcsolatnak megfelelően - döntöen központi/városi feladatok fejlesztését jelenti.

- Magyarországon hiányoznak azok a városok, amelyek az európai mércével közepes (300-600 ezres) városok hálójához tartoznak. Ennek ellenére azokat a funkciókat, amelyeket ezek a városok ellátnak, valamelyik településnek, településeknek teljesíteniük kell. Azon funkciókat, amelyek ellátása egy szervezetben a leghatékonyabb, azokat a továbbiakban is Budapesten célszerủ teljesíteni, azokat, amelyek ellátása igényli a földrajzi közelséget és l-2 millió fö ellátása adja a gazdaságos teljesítés alapját a regionális központokba, a 3-400 ezres feladatok ellátását a nagyvárosokba kell koncentrálni. A különbözỏ szintủ régiók erösítése szorosan összefügg a központi települések megerösítésével.

- A vidék sajátosságaira figyelemmel (pl. aprófalvas vagy tanyás térség) fent kell tartani speciális támogatási lehetőségeket

- a gazdasági diverzifikáció előmozdítására, a foglalkoztatási lehetỏségek bövítésére,

- az agrárium fejlesztésére,

- a máshol igénybeveendő szolgáltatások, a munkalehetőségek elérhetöségének javítására,

- a környezet állapotának fenntartására és javítására,

- az életminőség javítására,

- a tartós válságkezelésre.

\section{Jegyzetek}

${ }^{1}$ A területi tudományokban a helyi (lokális) és a nemzeti szint közötti területegységeket régióknak nevezzük.

${ }^{2}$ A görög eredetú poli- előtag jelentése sok-, több-, az összetettségre utal.

${ }^{3}$ Emlékezzủnk csak az 1971-es OTK-t követô vitára. Nem mindegy, hogy a legkisebb, a legkevesebb funkciót ellátó telepulések „egyéb” vagy „alapfokú” minősítést/megnevezést kapnak.

${ }_{5}^{4}$ Könyvének első kiadása az 1890-es években jelent meg.

5 Sajnálatos, hogy ma Magyarországon egy város, kistérség, megye sem fogalmazza meg a reindusztrializáció szưkségességét.

${ }^{6}$ Európai területi tervezési és megfigyelö hálózat.

${ }^{7}$ Commission Staff Working Paper. Cohesion Policy and cities: the urban contribution to growth and jobs in the regions. 19-20. o. 
${ }^{8}$ The Territorial State and perspectives of the European Union Document. Towards a stronger European territorial cohesion in the light of the Lisbon and Gothenburg Ambitions. Scoping document and Summary of political messages. 2005. May. 20/21, Luxemburg.

${ }^{9}$ The Territorial State and perspectives of the European Union Document. Towards a Stronger European Territorial Cohesion in the Light of the Lisbon and Gothenburg Ambitions. First Draft, 2006. június 6. , Luxemburg.

10 A városhiắnyos területeken városok alakultak ki. meghatározta azokat a központi helyeket, amelyek nem tudják ellátni a megkívánt funkciókat stb.

11 Tértudományi értelemben a nemzeti és a helyi szint közötti têregységek regionálisak.

${ }^{12}$ Hasonló tévedés történt, amikor a területfejlesztésért felelös intézményt Magyar Terület és Regionális Fejlesztési Hivatalnak keresztelték el. Az elnevezés azt sugallta, hogy a regionális fejlesztés nem tartozik a területfejlesztés hatókörébe. E csorbát küszöbölte ki az Országos Területfejlesztési Hivatallá való átkeresztelés.

13 1996. évi XXI. törvény: 1. § (3) A településfejlesztésre és a településrendezésre külön törvény vonatkozik.

${ }^{14}$ Számos olyan önkéntes kistérségi társulás alakult, amelyböl kimaradt a centrum, a központi hely, a város. Sokan a várossal szembeni érdekérvényesítésben látták lehetóségeik növelését. A helyzet éppen ezzel ellentétes, az elérhető város fejlódése meghatározó a kisebb települések számárá.

15 A 177 oldalas háttéranyag körülbelül 5 oldalon foglalkozik a városokkal és a több mint 60 térkép egyike sem modellezi vagy koncepcionálja a városhálózatot.

16 E határozatok tartalmától már azok elfogadását követöen is több tárcavélemény eltért. Az NSRK (2007-2013) készítésére sem tartják meghatározónak.

\section{Irodalom}

Bibó I. (1986) Közigazgatási területrendezés és az 1971-es településhálózat-fejlesztési koncepció. - Bibó I. (1986) Vúlogatott Múvek. III. kötet 140-294. o.

Boudville, J.R. (1966) Problems of Regional Economic Planing. Edinburgh.

Christaller, W. (1933) Die zentralen Orte in Süddentschlaud. Jena, Gustav Fisher Verlag.

Erdei F. (1939/1974) Magyar város. (Hasonmás kiadás). Budapest, Akadémiai Kiadó.

Erdei F. (1931/1971) Város és vidéke. Szépirodalmi Könyvkiadó, Budapest.

Hantos Gy. (1931) A magyar közigazgatís terilleti alıpjai. Budapest.

Krugman, P. (1991) Geography and Trade. MTI Press, Cambridge.

Marshall, A. (1920) Principles of Economics. Macmillan, London.

Myrdal, G. (1957) Economic Theory and Underdeveloped Regionts. London.

Porter, M.E. (1990) The Competitive Adventage of Nations. The Free Press, New York.

Pottier, P. (1963) Axes de communication et dévelopment économiqe. - Revue Economique. 14. 58-132. o.

Perroux, F. (1955) Note sur la notion de pole de croissance. - Économie Appliquee. 1-2.

\section{CONCEPTIONAL ESTABLISHMENT OF TOWN BASED REGIONAL POLITICS}

\section{LÁSZLÓ FARAGÓ}

In this study I aim to write what can be the already known but forgotten bases of renewed (actually ,retro") regional politics -. How can city-village categories be integrated and what are the regional economical bases of city oriented development policies. After that I summarize the changes of EU regional politics concerning our topic. By describing Hungarian history of this topic I aim to show that these questions are not new ones, we have to give $21^{\text {th }}$ century answers to historical debts. New thing in ,retro" regional development policy is the policentical development based on city regions; what integrates rural places in a new way and recreates the old city-village dichotomy. Concentrated decentralization must be helped by correcting accessibility. 